\title{
Apoptosis of HeLa and CaSki cell lines incubated with All-trans retinoid acid
}

\section{Dorota Darmochwal-Kolarz ${ }^{1}$, Urszula Gasowska-Giszczak ${ }^{2}$, Robert Paduch ${ }^{3}$, Bogdan Kolarz ${ }^{4}$, Piotr Wilciński ${ }^{1}$, Jan Oleszczuk ${ }^{1}$, Anna Kwasniewska ${ }^{5}$}

\author{
${ }^{1}$ Department of Obstetrics and Perinatology, Medical University of Lublin, Poland \\ ${ }^{2}$ District Hospital of Lublin, Poland \\ ${ }^{3}$ Department of Virology and Immunology, Institute of Microbiology and Biotechnology, \\ University of Maria Curie-Sklodowska, Lublin, Poland \\ ${ }^{4}$ Department of Reumathology and Connective Tissue Diseases, Medical University of Lublin, Poland \\ ${ }^{5}$ Department of Obstetrics and Pathology of Pregnancy, Medical University of Lublin, Poland
}

\begin{abstract}
The aim of the study was to evaluate the concentrations of a soluble form of APO-1/Fas antigen (sFas, CD95) and a soluble Ligand for APO-1/Fas antigen (sCD95L, sFasL) in supernatants from CaSki and HeLa cell line cultures after the incubation with All-trans-retinoic acid. HPV-16 and HPV18 - positive cell lines were cultivated with All-trans-retinoic acid in concentrations of $1 \times 10^{-6} \mathrm{M} / \mathrm{L}$ and $1 \times 10^{-8} \mathrm{M} / \mathrm{L}$. The cultures were incubated for 24 hours. Control culture with $3 \mu \mathrm{l}$ of dimethyl-sulphoxide (DMSO) was incubated under identical conditions. The concentrations of soluble APO-1/Fas antigen and Fas Ligand in cell culture supernatants were estimated using immunoenzymatic methods. The obtained results showed significant decrease of concentrations of soluble APO-1/Fas antigen in supernatants from HeLa cell lines incubated with retinol in comparison with the control culture. Moreover, the concentrations of soluble Ligand for APO-1/Fas antigen in the supernatants of CaSki and HeLa cell lines were significantly lower in the culture incubated with All-trans retinoid acid when compared to the control culture. Higher concentrations of soluble APO-1/Fas antigen in supernatants from HeLa cell line without retinol may constitute a protective mechanism of the cells infected with the virus before undergoing Fas/FasL-dependent apoptosis. Lower concentrations of soluble APO-1/Fas antigen and soluble Ligand for APO-1/Fas in the supernatants from CaSki and HeLa cell cultures incubated with retinol suggest that retinoids can decrease the synthesis of soluble APO-1//Fas and soluble FasL in HPV-16 and HPV - 18 positive cells and that mechanisms protecting infected cells against Fas/FasL-mediated apoptosis become defective under the influence of retinol.
\end{abstract}

Key words: apoptosis, All-trans retinoic acid, CaSki cell line, HeLa cell line, soluble APO-1/Fas antigen, soluble Ligand for APO-1/Fas antigen

\section{Introduction}

The antigen of APO-1/FAS is a member of the TNF/NGF receptor family. It has three extracellular domains, rich in cysteine residues, and intracellular death domain (DD) responsible for transmitting of a pro-apoptotic signal [1-3]. The Ligand for APO-1/Fas antigen is a type II membrane protein that belongs to the tumor necrosis factor (TNF) family and induces apoptosis in Fas-expressing cells. The pro-apoptotic

Correspondence: D. Darmochwal-Kolarz, Dept. of Obstetrics and Perinatology, Medical University of Lublin, 20-950 Lublin, Jaczewskiego Str. 8, Poland; tel. (+4881) 7244769,

fax.: (+4881) 7244841, e-mail: dorotak@mp.pl signal is transmitted through the reaction of the receptor with agonistic antibodies or its cognate oligomerizing ligand (CD95L), which is present in cellular membrane or outside the cells in a soluble form [1-3].

The programmed cell death Fas/FasL - mediated takes part mainly in a regulation of an immune response and a body tissue homeostasis. Many studies suggest the additional functions of this system, especially their important role in pathogenesis of many diseases characterized by decreased or excessive apoptosis [1-3].

The mechanisms of signal transmission by APO$1 /$ Fas receptor (CD95) and the role and activity of CD95 Ligand can allow for better understanding of many diseases including neoplastic lesions. 
Recent findings suggest that Fas and FasL antigens are essential for cell death process and that any dysfunction in this system can lead to a breakdown in peripheral tolerance [2-6].

The soluble forms of APO-1/Fas molecule are produced as translation products of alternatively spliced mRNA [4-8]. The secreted receptors represent truncated forms of the membrane-bound receptors that can bind a ligand in a way similar to that of their membrane-bound counterparts [4-8]. As a result, these receptors play an important role in the regulation of normal receptor activity. Cheng et al. found that soluble Fas is capable to inhibit Fas-mediated apoptosis in vitro [9]. As previously noted, Fas mRNA is expressed by most cells, and to a variable extent all cells expressing Fas may be responsible for the potential sources of any form of soluble Fas [4-8]. Regardless of their sources, higher concentrations of soluble Fas antigen can influence ability of cells to undergo Fas/FasL mediated programmed cell death process [9-11].

Retinoids belong to immunosuppressive factors negatively regulating activation-induced CD95L expression. They may be natural or synthetic, structurally connected with vitamin A group. They display antiproliferative activity and stimulate differentiation of neoplastic cells. This feature has been used in prophylactics and therapy of various types of human neoplasms, e.g. cervical cancer, and precancerous conditions [12-15]. In the studies performed it was speculated that activity of retinoids is related with blocking of mRNA expression for CD95 Ligand. However, lack of responsive elements in $\mathrm{CD} 95 \mathrm{~L}$ promotor region suggests the existence of indirect mechanisms e.g. hyperexpression of IkB and interference with NF-kB [1215]. Currently it is thought that retinoid activity is the result of their ability of binding to specific nuclear receptors acting as ligand-dependent transcription factors [12-15].

Studies with a purpose of explaining retinoid activity are usually performed using cellular culture models. The model of latent infection of cervical cells with oncogenic HPV-18 for in vitro examinations is $\mathrm{HeLa}$ line cells culture. It is used in basic studies of cytotoxic and genotoxic characteristics of medicines, regulation of gene expression and cell reaction to stress.

The aim of this study was to evaluate the concentrations of soluble APO-1/Fas antigen and soluble Fas Ligand in supernatants from CaSki and HeLa cell line cultures after 24 hours of incubation with selected retinoic acid concentrations.

\section{Material and methods}

Cell culture and growth condition. HPV-16 - positive cell lines (CaSki cell lines) and HPV-18 - positive cell lines (HeLa cell lines - ECACC 95051229) were cultivated in RPMI 1640 medium supplemented with $10 \%$ fetal calf serum (FCS) and antibiotics in a humidified $5 \% \mathrm{CO}_{2}$ incubator at $37^{\circ} \mathrm{C}$. The antibiotics were administered in the following concentrations: penicillin $100 \mathrm{IU} / \mathrm{ml}$ and streptomycin $100 \mu \mathrm{g} / \mathrm{ml}$. The number of cells in the culture wells was $10^{5} / \mathrm{ml}$. All-trans-retinoic acid (ATRA, Sigma, USA) was dissolved in DMSO and added to the culture in concentrations of $1 \times 10^{-6} \mathrm{M} / \mathrm{L}$ and $1 \times 10^{-8} \mathrm{M} / \mathrm{L}$ [5-7]. Cell cultures were incubated for 24 hours. Control culture with $3 \mu 1$ of DMSO was incubated under identical conditions. After incubation the supernatants were centrifuged, in order to be clarified prior to use in the assay. Samples were stored at $-20^{\circ} \mathrm{C}$.

The concentrations of soluble APO-1/Fas antigen in cell culture supernatants were measured using a quantitative enzymelinked immunosorbent assay ELISA (Human sAPO-1/Fas ELISA, Bender MedSystems, Diagnostics GmbH, Vienna, Austria). Standard dilutions of sAPO-1/Fas antigen were prepared in concentrations ranging from $16 \mathrm{pg} / \mathrm{ml}$ to $1000 \mathrm{pg} / \mathrm{ml}$. The measurements were performed in duplicates. Wells designated for samples were filled with $10 \mu \mathrm{l}$ of each sample of the supernatant, $90 \mu \mathrm{l}$ of Sample Diluent and $50 \mu \mathrm{l}$ Biotin Conjugate $(10 \mu \mathrm{l} / \mathrm{ml})$ and then covered with Plate Cover and incubated at $37^{\circ} \mathrm{C}$ for 1 hour.

After incubation wells had been emptied and washed 3 times with $300 \mu \mathrm{l}$ Wash Buffer per well. Next, $100 \mu \mathrm{l}$ of diluted $(4 \mu \mathrm{l} / \mathrm{ml})$ Streptavidin-HRP was added to all wells. Then the plate was incubated again at $37^{\circ} \mathrm{C}$ for 1 hour.

Wells were emptied again, washed 3 times like before and 100 $\mu l$ of TMB Substrate Solution was added. After incubation at room temperature for 15 minutes on a rotator, enzyme reaction was stopped by quickly pipetting $100 \mu \mathrm{l}$ of Stop Solution into each well. Results were read immediately on spectro-photometer using $450 \mathrm{~nm}$ wave length.

The concentrations of soluble Fas Ligand in cell culture supernatants were measured using a quantitative enzyme-linked immunosorbent assay ELISA (Human sFas Ligand ELISA, MBL Medical and Biological Laboratories, Co. Ltd., Nagoya, Japan). Standard dilutions of soluble Fas Ligand were prepared in concentrations ranging from $0 \mathrm{ng} / \mathrm{ml}$ to $5 \mathrm{ng} / \mathrm{ml}$. The measurements were performed in duplicates. Antibody coated wells were filled with $100 \mu \mathrm{l}$ of prepared samples of the supernatants and standards and incubated at room temperature for one hour. After incubation wells had been emptied and washed four times with Wash solution. Next, $100 \mu \mathrm{l}$ of Conjugate solution was added to all wells. Then the plate was incubated again at room temperature for one hour. Wells were emptied again, washed four times like before and $100 \mu \mathrm{l}$ of Substrate Solution was added. After incubation at room temperature for 30 minutes, enzyme reaction was stopped by quickly pipetting $100 \mu 1$ of Stop Solution into each well. Results were read immediately on spectro-photometer using $450 \mathrm{~nm}$ wave length.

Statistical analysis. Statistical differences between groups were estimated using a standard non-parametric test (Mann-Whitney U test). The results were presented as mean with SD and ranges. Differences at $p<0.05$ were considered as statistically significant. Statistica 7.0 PL software was applied to statistical analysis.

\section{Results}

The concentrations of soluble Fas Ligand in the supernatant of HPV-16 positive (CaSki) cell line culture were significantly lower in the culture incubated with $10^{-6} \mathrm{M} / \mathrm{L}$ of All-trans retinoid acid when compared to the control culture (CaSki cell line with ATRA 10-6 $\mathrm{M} / \mathrm{L} v$ s. control, $\mathrm{p}<0.05)$.

The concentrations of soluble Fas/APO-1 antigen in the supernatants of HPV-18 positive (HeLa) cell line cultures after the incubation with $10^{-8} \mathrm{M} / \mathrm{L}$ and with 
Tab.1. The concentrations of soluble APO-1/Fas antigen in HPV-16 (CaSki) cell line cultures incubated without All-trans Retinoid acid (control) and with different concentrations of All-trans Retinoid Acid $\left(1 \times 10^{-6} \mathrm{M} / \mathrm{L}, 1 \times 10^{-8} \mathrm{M} / \mathrm{L}\right)$ for 24 hours.

\begin{tabular}{|c|c|c|c|}
\hline $\begin{array}{c}\text { The concentrations of All-trans } \\
\text { Retinoid } \Lambda \text { cid }(\mathrm{M} / \mathrm{L})\end{array}$ & $\begin{array}{c}\text { The time of incubation } \\
\text { (hours) }\end{array}$ & $\begin{array}{c}\text { The concentrations of soluble } \\
\Lambda \mathrm{PO}-1 / \text { Fas antiget }(\mathrm{p} / \mathrm{ml})\end{array}$ & $\mathrm{P}$ \\
\hline control & 24 & 91,99 & $\begin{array}{c}\text { Control vs R } 10^{-6} \\
\mathrm{NS}\end{array}$ \\
\hline $10^{-6}$ & 24 & 59,12 & $\begin{array}{c}\text { RA } 10^{-6} \mathrm{vs} \mathrm{RA} 10^{-8} \\
\text { NS }\end{array}$ \\
\hline $10^{-8}$ & 24 & 54,16 & $\begin{array}{c}\text { R } \Lambda 10^{-8} \mathrm{vs} \mathrm{control} \\
\mathrm{NS}\end{array}$ \\
\hline
\end{tabular}

Tab. 2. The concentrations of soluble APO-1/Fas antigen in HPV-18 (HeLa) cell line cultures incubated without All-trans Retinoid Acid (control) and with different concentrations of All-trans Retinoid Acid $\left(1 \times 10^{-6} \mathrm{M} / \mathrm{L}, 1 \times 10^{-8} \mathrm{M} / \mathrm{L}\right)$ for 24 hours.

\begin{tabular}{|c|c|c|c|}
\hline $\begin{array}{c}\text { The concentrations of All-trans } \\
\text { Retinoid Acid }(\mathrm{M} / \mathrm{L})\end{array}$ & $\begin{array}{c}\text { The time of incubation } \\
\text { (hours) }\end{array}$ & $\begin{array}{c}\text { The concentrations of soluble } \\
\text { APO-l/las antigen }(\mathrm{pg} / \mathrm{ml})\end{array}$ & $\mathrm{P}$ \\
\hline control & 24 & 298.3 & $\begin{array}{c}\text { Control vs RA } 10^{-6} \\
\mathrm{P}<0.05\end{array}$ \\
\hline $10^{-6}$ & 24 & 35.03 & $\begin{array}{r}\text { RA } 10^{-6} \mathrm{vs} \text { R } \\
\text { NS } 10^{-8}\end{array}$ \\
\hline $10^{-8}$ & 24 & 40.25 & $\begin{array}{r}\text { RA } 10^{-8} \mathrm{vs} \text { control } \\
\mathrm{P}<0.05\end{array}$ \\
\hline
\end{tabular}

Tab. 3. The concentrations of soluble Fas Ligand in HPV-16 (CaSki) cell line cultures incubated without All-trans retinoid acid (control) and with different concentrations of All- trans retinoid acid $\left(1 \times 10^{-6} \mathrm{M} / \mathrm{L}, 1 \times 10^{-8} \mathrm{M} / \mathrm{L}\right)$ for 24 hours.

\begin{tabular}{|c|c|c|c|}
\hline $\begin{array}{c}\text { The concentrations of All-trans } \\
\text { Retinoid } \Lambda \text { cid }(\mathrm{M} / \mathrm{L} \text { ) }\end{array}$ & $\begin{array}{c}\text { The time of incubation } \\
\text { (hours) }\end{array}$ & $\begin{array}{c}\text { The concentrations of soluble } \\
\Lambda \mathrm{PO}-1 / \text { Fast antigen }(\mathrm{ng} / \mathrm{ml})\end{array}$ & $\mathrm{P}$ \\
\hline control & 24 & 0,027 & $\begin{array}{c}\text { Control vs R } 10^{-6} \\
\mathrm{P}<0.005\end{array}$ \\
\hline $10^{-6}$ & 24 & 0,012 & $\begin{array}{c}\text { RA } 10^{-6} \mathrm{vs} \mathrm{RA} 10^{-8} \\
\mathrm{P}<0.005\end{array}$ \\
\hline $10^{-8}$ & 24 & 0,026 & $\begin{array}{c}\text { R } \Lambda 10^{-8} \mathrm{vs} \mathrm{control} \\
\mathrm{NS}\end{array}$ \\
\hline
\end{tabular}

Tab. 4. The concentrations of soluble Fas Ligand in HPV-18 (HeLa) cell line cultures incubated without All-trans Retinoid Acid (control) and with different concentrations of All-trans retinoid Acid $\left(1 \times 10^{-6} \mathrm{M} / \mathrm{L}, 1 \times 10^{-8} \mathrm{M} / \mathrm{L}\right)$ for 24 hours.

\begin{tabular}{|c|c|c|c|}
\hline $\begin{array}{l}\text { The concentrations of } \wedge \text { ll-trans } \\
\text { Retinoid } \wedge \text { cid }(M / I \text { ) }\end{array}$ & $\begin{array}{l}\text { The time of incubation } \\
\text { (hours) }\end{array}$ & $\begin{array}{l}\text { The concentrations of soluble } \\
\Lambda \mathrm{PO}-1 / \text { FasI, antigen }(\mathrm{ng} / \mathrm{ml})\end{array}$ & $\mathrm{P}$ \\
\hline control & 24 & 0,040 & $\begin{array}{c}\text { Control vs RA } 10^{-6} \\
P<0.05\end{array}$ \\
\hline $10^{-6}$ & 24 & 0,023 & $\begin{array}{c}\text { RA } 10^{-6} \text { vs RA } 10^{-8} \\
P<0.05\end{array}$ \\
\hline $10^{-8}$ & 24 & 0,034 & $\begin{array}{c}\mathrm{R} \wedge 10^{-8} \text { vs control } \\
\text { NS }\end{array}$ \\
\hline
\end{tabular}

$10^{-6} \mathrm{M} / \mathrm{L}$ of retinol were significantly lower when compared to the control (HeLa cell line with $10^{-8} \mathrm{M} / \mathrm{L}$ of ATRA vs. control, $\mathrm{p}<0.005$; HeLa cell line with $10^{-}$ ${ }^{6} \mathrm{M} / \mathrm{L}$ of ATRA vs. control, $\left.\mathrm{p}<0.005\right)$.

The concentrations of soluble Fas Ligand in the supernatant of HPV-18 positive (HeLa) cell line culture were significantly lower in the culture incubated with $10^{-6} \mathrm{M} / \mathrm{L}$ of All-trans retinoid acid when compared to the control culture (HeLa cell line with ATRA $10^{-6} \mathrm{M} / \mathrm{L}$ vs. control, $\left.\mathrm{p}<0.005\right)$.

The concentrations of soluble Fas/APO-1 antigen in the supernatants of HPV-16 positive (CaSki) cell line cultures did not differ significantly when compared to the control culture. The results are shown in Table 1-4. 


\section{Discussion}

Although the expression of CD95 Ligand (FasL) was initially believed to be confined to activated $\mathrm{T}$ cells, several other cell types have subsequently been shown to produce and release this antigen. FasL is constitutively expressed in neutrophils, neurons, thyrocytes, stroma cells of the retina, acinar cells in salivary glands, Sertoli cells and trophoblast cells [10]. Moreover, a variety of cell types can express FasL in response to different stimulatory conditions, including macrophages infected with human immunodeficiency virus, hepatocytes treated with ethanol, leukemia cells exposed to chemotherapy drugs and various cell types upon tumor transformation $[10,11]$. The functional soluble form of FasL is responsible for killing Fas-sensitive cells through either autocrine or paracrine suicide death $[10,11]$.

In our study we observed decreased concentrations of soluble CD95 Ligand in the CaSki and HeLa cell line culture supernatants incubated with retinol.

It has been observed lately that resistance to apoptosis was associated with an increased release of soluble Fas antigen or with posttranscriptional regulation of CD95 caused by some substances like N-acetyl-Lcysteine, cyclosporine-A and FK506 [3]. Other immunosuppressive agents are also able to negatively regulate activation - induced CD95L expression. Dexomethasone, which induces $\mathrm{T}$ cell apoptosis by itself, also inhibits CD95L expression. Retinoic acid shows similar effects. Because no obvious glucocorticoid and/or retinoid response elements were found in the CD95L promoter, it was concluded that dexomethasone and retinoic acid are likely to inhibit $\mathrm{CD} 95 \mathrm{~L}$ expression by indirect mechanism, involving e.g. hyperexpression of $\mathrm{IkB}$ and interference with NFkB [12-15].

Most of the studies have described retinol as inhibitor of cell growth. In G1 phase, retinoic acid increases the level of p27 kip1 (cdk inhibitor) due to direct regulation of p27kip 1 gene expression by RAR (retinoic acid receptor). Landelfeld reported that retinoic acid induced growth arrest due to enhanced ubiquitin-dependent degradation of cyclin D1 [16]. While, Teixeira presents that retinoic acid reduces the mRNA level of cyclin D1 and cdk-2 [17].

There are some specific effects of retinoids. The major biological activities of retinoids are thought to be mediated by two types of nuclear retinoids receptors, RARs and retinoid X receptors, which are members of the steroid hormone receptor gene superfamily [18]. Retinoids can increase the expression of Fas antigen and augment Fas/FasL-induced apoptosis in cell line with wild-type p53 but not in cell lines having mutant p53 [19]. Furthermore, it has been decribed lately that retinoids inhibit Fas ligand (FasL) expression and repress the activation-induced apoptosis of immature thymocytes and T-cell hybridomas. Alltrans-RA represses the trancriptional activity of nuclear factors of activated T-cells (NFAT), which is an important transactivator of the FasL promoter [20].

In this study we are showing that HeLa cell line infected by HPV-18 express high level of soluble APO-1/Fas antigen, which probably protects it against apoptosis and this effect is diminished by retinoid acid. Similar results have been shown in human hepatocellular carcinoma and human lung cancer cell lines $[21,22]$. The concentrations of soluble Fas/APO-1 antigen in HeLa cell line culture with all-trans-retinoic acid (ATRA) were downregulated when compared with HeLa cell line without ATRA. We did not observed these effects in the CaSki cell line cultures incubated with retinol. These observations suggest different mechanisms of retinoids influence on HPV-16 and HPV-18 infected cell lines.

On the other hand, Zhu et al. studied the influence of ATRA on the expressions of bcl-2, Fas and FasL antigen mRNA on murine lymphoma cell line. They observed that ATRA downregulated the expression of bcl-2 without any change of Fas and FasL antigens [23]. Activation of the Fas/FasL system is considered not to be involved in retinoic-induced apoptosis. On the other hand, a number of herpesviruses of gamma type were shown to inhibit all death-receptor-mediated apoptosis by expressing a gene product that directly interacts with caspase- 8 and thereby inhibits the formation and activity of the death-inducing signaling complex [24]. Additionally, a number of viruses express a functional $\mathrm{Bcl}-2$ analog, such as E1B by EBV or ORF 16 by HHV-8 [25].

\section{Conclusions}

Higher concentrations of soluble APO-1/Fas antigen in supernatants from HeLa cell line without retinol may constitute a protective mechanism of the cells infected with the virus before undergoing Fas/FasL-dependent apoptosis. Decreased concentrations of sAPO-1/Fas antigen in HeLa cell line cultures incubated with retinol may suggest that mechanisms protecting infected cells against Fas/FasL-mediated apoptosis become defective under the influence of retinol.

Decreased concentrations of CD95 Ligand in Caski and HeLa cell line cultures incubated with retinol may suggest that retinoids can inhibit the synthesis of soluble Fas Ligand in HPV-16 and HPV-18 positive cell lines.

Our studies confirm that vitamin A and its analogs inhibit proliferation of cells associated with HPV infection and suggest promising effects of retinoid therapy in inhibiting the progression of early cervical lesions into cancer.

Acknowledgements: The work was supported by grant of Ministry of Science and Higher Education Nr 2 P05E 05630. 


\section{References}

[ 1] Peter ME, Krammer PH. Mechanisms of CD95 (APO-1/Fas) mediated apoptosis. Curr Opinion Immunol. 1998;10:545-551.

[2] Genestier L, Bonnefoy-Berard N, Revillard JP. Apoptosis of activated peripheral T cells. Transplant Proc. 1999;31:33-38.

[3] Lynch DH, Ramsdell F, Alderson MR. Fas and FasL in the homeostatic regulation of immune responses. Immunol Today. 1995; 16:569-574.

[ 4] Wyllie AH. Death gets a break. Nature 1994;369:272-273.

[5] Wyllie AH, Kerr JFR, Curie AR. Cell death: the significance of apoptosis. Inter Rev Cytol. 1980;65:251-306.

[6] Nagata S, Golstein P. The Fas death factor. Science. 1995;267: 1449-1456.

[ 7] Klaassen I, Brakenhoff RH, Smeets SJ, Snow GB, Braakhuis BJ. Considerations for in vitro retinoid experiments: importance of protein interaction. Biochim Biophys Acta. 1999; 1427:265-275.

[8] Raff MC. Social controls on cell survival and cell death. Nature. 1992;356:397-400.

[ 9] Cheng J, Zhou T, Lin C, Shapiro JP, Brauer MJ, Kiefer MC, Barr PJ, Mountz J. Protection from Fas-mediated apoptosis by a soluble form of the Fas molecule. Science. 1994;263: 1759-1762.

[10] Suda T, Okazaki T, Naito Y. Expression of the Fas and Fas ligand in cells of T cell lineage. J Immunol. 1995;154:3806-3813.

[11] Griffith TS, Fergusson TA. The role of FasL - induced apoptosis in immune privilege. Immunol Today. 1997;18:240-244.

[12] Kwasniewska A, Tukendorf A. The concentrations of retinol in sera of women infected with HPV and with displastic changes of cervix. Med Dosw Mikrobiol. 1996;48:71-77.

[13] Agarwal C, Hembree JR, Rorke EA, Eckert RL. Interferon and retinoic acid supress the growth of human papillomavirus type 16 immortalized cervical epithelial cells, but only interferon suppresses the level of human papillomavirus transforming oncogenes. Cancer Res. 1994;54:2108-2112.

[14] Behbakht K, DeGeest K, Turyk ME, Wilbanks GD. All-trans retinoic acid inhibits the proliferation of cell lines derived from human cervical neoplasia. Gynecol Oncol. 1996;61:31-39.

[15] Narayanan BA, Holladay EB, Nixon DW, Mauro CT. The effect of atRA and 9-cisRA on the steady state level of HPV
16 E6/E7 mRNA and cell cycle in cervical carcinoma cells. Life Sci. 1998;63:565-573.

[16] Lagenfeld J, Kiyokawa H, Sekula D, Boyle J, Dmitrovski E. Posttranslational regulation of cyclin D1 dy retinoic acid: a chemoprevention mechanism. Proc. Natl Acad Sci USA. 1997;94:12070.

[17] Teixeira C, Pratt M.A. CDK2 is a target for retinoic acid mediated growth inhibition in MCF-7 human breast cancer cells. Mol Endocrinol. 1997;11:1191.

[18] Chambon P. A decade of molecular biology of retinoic acid receptors. FASEB J. 1996;10:940-954.

[19] Sun SY, Yue P, Hong WK, Lotan R. Induction of Fas expression and augmentation of Fas/Fas ligand-mediated apoptosis by the synthetic retinoid CD437 in human lung cancer cells. Cancer Research. 2000;60:6537-6543.

[20] Lee MO, Kang HJ, Kim YM, Oum JH, Park J. Repression of FasL expression by retinoic acid involves a novel mechanism of inhibition of transactivation function of the nuclear factors of activated T-cells. Eur J Biochem. 2002;269(4):1162-1170.

[21] Yano H, Fukuda K, Haramaki M, Momosaki S, Ogasawara S, Higaki K, Kojiro M. Expression of Fas and anti-Fas-mediated apoptosis in human heaptocellular carcinoma cell lines. $J$ Hepatol. 1996;25:454-464.

[22] Mitani K, Nishioka Y, Yamabe K, Ogawa H, Miki T, Yanagawa $\mathrm{H}$, Sone S. Soluble Fas in malignant pleural effusion and its expression in lung cancer cells. Cancer Sci. 2003;94: 302-307.

[23] Zhu HL, Wang YZ, Yu L, Li B, Yao SQ, Lou FD. The expression of Fas, FasL and bcl-2 on RMA cells during the process of apoptosis induced by chemotherapeutic drugs. Zhongguo Shi Yan Xue Ye Xue Za Zhi. 2002;10(1):35-39.

[24] Thome M, Schneider P, Hofmann K, Fickenscher H, Meinl E, Naipel F, Mattmann C, Burns K, Bodmer JL, Schroter M, Scaffidi C et al. Viral FLICE - inhibitory proteins (FLIPs) prevent apoptosis induced by death receptors. Nature. 1997; 386:517-521.

[25] Tschopp J, Thome M, Hofmann K, Meinl E. The fight of viruses against apoptosis. Curr Opin Genet Dev. 1998;8:82-87.

Submitted: 24 April, 2009 Accepted after reviews: 7 July, 2009 